\title{
Investigating value-laden leadership styles among family business owners
}

\author{
E. Venter* and S.M. Farrington \\ Department of Business Management, Nelson Mandela Metropolitan University, \\ P O Box 77000, NMMU South Campus, Port Elizabeth 6031, South Africa \\ *To whom all correspondence should be addressed \\ Elmarie.Venter@nmmu.ac.za
}

\begin{abstract}
Given the need for a different approach to leadership, as well as the need for further investigation on leadership among family businesses, this study investigates several value-laden leadership styles among family businesses. More specifically the primary objective is to establish the levels of Servant, Ethical, Authentic, and Participative leadership displayed by family business owners and the influence thereof on the Perceived business performance of the family business. A survey was undertaken and 266 usable questionnaires were returned from 133 family business owners and 133 from family business employees. The data analysis involved calculating descriptive statistics and undertaking t-tests. Multiple regression analysis (MRA) was done to test the hypothesised relationships. Although the MRA analysis revealed no statistically significant relationships between the leadership styles investigated and Perceived business performance, the vast majority of respondents agreed that the styles investigated were displayed by the family business owners. For both sample groups Ethical leadership returned the highest mean score, followed by Servant and Participative leadership. The importance of these value-laden leadership styles to family businesses is thus highlighted, contradicting the literature that family businesses owners are often autocratic in their leadership style. In addition, increased clarity on the effectiveness of these value-laden leadership styles within the context of family business is provided.
\end{abstract}

\section{Introduction}

The importance of family businesses to the economies of countries (Zellweger, 2015; Global data points, 2014), as well as their high failure rates (Tanzwani, 2010: 2; Ibrahim, McGuire \& Soufani, 2009: 1), is well documented. Various reasons are put forward for these high failure rates, but several sources (Myatt, 2009; Rushin, n.d.) contend that the failure of many businesses, including those that are familyowned, is simply the result of poor leadership. Business watchdogs around the world have raised serious concerns about leadership in businesses (Choudhary, Akhtar \& Zaheer, 2013: 433) and the global economic recession has provoked researchers to investigate and define new models of ethical leadership styles (Choudhary et al., 2013: 433). Perceptions of leadership are changing and a need for a leadership model that promotes ethics and high moral standards rather than one based on power and authority, has arisen (Hackett \& Wang, 2012: 868). Several authors (Avolio, Walumbwa \& Weber, 2009: 422-423; Kar, 2009: 112; Sendjaya, Sarros \& Santora, 2008: 402) assert that a need exists to research, develop and implement more ethical, dyadic, inclusive and relational, value-laden leadership styles.

According to Kar (2009: 114), leadership begins with an understanding of and commitment to an individual's core values. In addition, Gini (1997: 325) is of the opinion that the real role of leadership is to manage the values of an organisation and that all leadership is value-laden and moral. From a socioemotional wealth perspective (Berrone, Cruz \& Gomez-Mejia, 2012), value-laden leadership is of the utmost importance in family businesses, if not more so than in their non-family counterparts. The importance of values, the perpetuation of family values through the business, the preservation of the family dynasty, and the conservation of the family's social capital is frequently highlighted in the literature (Gomez-Mejia, Cruz, Berrone \& De Castro, 2011: 655; Ceja, Agulles \& Tàpies, 2010: 2). In other words, family businesses are typically committed to the preservation of their socioemotional wealth, referring to the nonfinancial aspects or "affective endowments" of family owners (Berrone et al., 2012: 259). The presence of strong family values and owner motivations are what give family businesses their distinct organisational culture (Gomez-Mejia et al., 2011: 655). We are of the opinion that to ensure the preservation of the family's socioemotional wealth, value-laden leadership styles should be adopted.

\section{Problem definition}

Despite the relationship between effective leadership and business outcomes being well supported in the literature (Jing \& Avery, 2008: 68; Kaiser, Hogan \& Craig, 2008: 96; Pedraja-Rejas, Rodríguez-Ponce \& Rodríguez-Ponce, 2006: $500)$, leadership remains one of the least understood topics in the field of family business. In their analysis of almost all existing family business-related writing, Xi, Kraus, Filser and Kellermanns (2015: 127) note "that the absence of the application of leadership theories is striking" and that over the years leadership had received little attention in the family business literature (Xi et al., 2015: 129). Although some efforts (Aldrich \& Cliff, 2003; Sorenson, 2000; Dyer, 1986) have been made to understand the leadership styles adopted by family business owners, Sharma (2004: 11) contends that these findings are inconclusive and suggests a need for further research on this topic. Litz, Pearson and Litchfield (2012: 23) posit that one of the greatest challenges facing the field of family business is to enhance the "understanding of complex, 
nuanced family business issues", including, amongst others, the leadership styles adopted in these businesses. Furthermore, although various leadership styles have been observed among family business owners, a lack of clarity exists on which styles would be most effective under which circumstance (Benavides-Velasco, Quintana-Garcia \& Guzman-Parra, 2013: 49-50). In summary, a lack of understanding exists on the leadership styles adopted by family business owners and a need exists for further research on this topic among these businesses.

\section{Research objectives}

Given the need for a different approach to leadership, as well as the need for further investigation on leadership among family businesses, this study investigates several value-laden leadership styles among small and medium-sized family businesses. The following research questions are posed: What is the level of Servant, Ethical, Authentic, and Participative leadership displayed by family business owners? Does the level of these styles displayed by the family business owners differ in terms of the perceptions the owner themselves hold and the perceptions held by their employees? Does the level of Servant, Ethical, Authentic, and Participative leadership displayed by the family business owners influence the performance of their businesses?

\section{Literature review and hypotheses development}

Balancing the diverse demands of the business, family, management and ownership systems, leadership in a family business is more complex than in a non-family business, and presents unique challenges for the family business owner (Aronoff \& Baskin, 2011). Sharma (2004: 12) suggests that the personality traits, long-term goals and life stage of the family business owner influences the leadership style evident in the family business.

According to Dyer (1986) in Sorenson (2000: 185), the most prominent type of family business culture is paternalistic. The paternalistic culture is best described as an autocratic approach to leadership where relationships are arranged hierarchically and leaders hold onto information and decision-making authority (Sorenson, 2000: 185). According to Davis (2014), however, effective leaders in family businesses are clearly "servant leaders" or "servant partners". These leaders typically have strong ideas and principles about how their businesses should be managed, what their coowners should invest in, and how their families should behave. Furthermore, Davis emphasises that family business leaders want to do their best for their followers and they behave like servants of the greater good.

\section{Value-laden leadership styles}

According to Sendjaya et al. (2008: 402), value-laden leadership styles include, amongst others, transformational leadership, authentic leadership, spiritual leadership and servant leadership. For the purpose of this study it was decided to investigate Servant, Ethical, Authentic, and
Participative leadership styles, as these styles are all valueorientated (Kar, 2009; Sendjaya et al., 2008).

Sendjaya et al. (2008: 405) define servant leadership as the leader being follower-orientated and displaying service, spiritual and moral dimensions of leadership. Van Dierendonck (2011: 1228), Russell and Stone (2002:146), as well as Page and Wong (2000) describe servant leaders as individuals who have characteristics such as serving the needs of others, integrity, humility, empathy, persuasion, caring for others, and authenticity. Brown, Trevino and Harrison (2005: 120) define ethical leadership as "the demonstration of normatively appropriate conduct through personal actions and interpersonal relationships, and the promotion of such conduct to followers through two-way communication, reinforcement and decision-making". Ethical leaders display attributes such as fairness, integrity, ethical guidance, power sharing, moral principles, openness, prudence, pride and honesty (Yukl, Mahsud, Hassan \& Prussia, 2013: 38; Bello, 2012: 228; Kalshoven, Den Hartog \& De Hoog, 2011: 51; Khuntia \& Suar, 2004: 15). Authentic leadership is defined as a pattern of leader behaviour that draws upon and promotes a positive ethical climate to foster an improved self-awareness and an internalised moral perspective, a balanced processing of information, and relational transparency on the part of the leader (Sendjaya et al., 2008: 402-403; Walumbwa, Avolio, Gardner, Wernsing \& Peterson, 2008: 94). Authentic leaders display traits such as openness, transparency, encouraging of self-development, and self-awareness (Walumbwa et al., 2008: 92; Gardner, Avolio, Luthans, May \& Walumbwa, 2005: 345). Participative leadership, also known democratic leadership, is defined as joint decision-making, or at least, shared influence in decision-making, by a leader and his/her employees (Koontz \& Weihrich, 2010: 314; Somech \& Wenderow, 2006: 747,763). Consultation, empowerment, support, development, recognition and leading by example are associated with participative leaders (Michel, Lyons \& Cho, 2011: 495). Despite these various leadership styles existing, one particular style may be more appropriate than another depending on the circumstances at hand (Somech \& Wenderow, 2006: 747). The leadership styles discussed above serve as the independent variables and Perceived business performance of the family business serves as the dependent variable in this study.

\section{Perceived business performance}

To date, no appropriate measure of business performance exists (Mahmood \& Hanafi, 2013: 84; Soininen, Martikainen, Pumaonen \& Kylaheiko, 2012: 616; Acs, Glaser, Litan \& Fleming, 2008: 11). Numerous studies make use of perceived measures of performance when assessing business performance (Wiklund \& Shephard, 2003; Lumpkin \& Dess, 1996). Perceived measures of business performance are typically based on the subjective views of the owner or manager regarding the growth and profitability of a business (Soininen et al., 2012: 616). Perceived measures can be an effective way to examine business performance as they allow comparison across firms and contexts, such as industry type, 
time horizons, cultures, or economic conditions (Song, Droge, Hanvanich \& Calantone, 2005: 262). The same approach to measuring business performance will be adopted in this study. Therefore, for the purpose of this study, business performance will be measured in terms of both the growth and profitability of the family business as perceived by the family business owner, and is referred to as Perceived business performance. Perceived business performance will be operationalised as the family business being profitable, successful and financially secure, as well as experiencing growth in profits, turnover, and number of employees over the last two years. As previously mentioned Perceived business performance serves as the dependent variable in this study. Therefore, the relationships between the various leadership styles and business performance are discussed in the following section.

\section{Hypotheses development}

Both anecdotal (Berghoefer \& Schwartz, 2014; Strider, 2011) and empirical (Yukl et al., 2013: 41; Zhu, May \& Avolio, 2004: 16) evidence suggest a positive relationship between ethical leadership and business performance. Both Berghoefer and Schwartz (2014), as well as Abiodun and Siddiq (2013: 2), highlight the importance of ethical leadership for business performance, whereas Strider (2011) contends that ethical leaders focus on building positive relationships which in turn positively influences business performance. Empirical studies report that ethical leadership has a positive influence on the attitudes and ethical behaviour of employees, which in turn positively influences the performance of the business (Bello, 2012: 231; Brown et al., 2005: 130; Trevino, Brown \& Hartman, 2003: 6). Against this background, the following hypothesis is subjected to empirical testing:

$H^{1}$ : There is a positive relationship between the family business owner displaying Ethical leadership and the Perceived business performance of the family business.

A growing body of evidence exists suggesting that an authentic approach to leading is desirable and effective for achieving positive outcomes for businesses (Walumbwa et al., 2008: 91; Gardner \& Schermerhorn, 2004: 278). Authentic leadership fosters both leaders' and followers' authenticity and development, resulting in positive wellbeing and genuine sustained performance (Wong \& Laschinger, 2012: 948). The positive influence of authentic leaders on employee performance is well supported in the literature (Wang, Sui, Luthans, Wang \& Wu, 2014: 7; Wong \& Laschinger, 2012: 948; Walumbwa et al., 2008: 91; Avolio, Gardner, Walumbwa, Luthans \& May, 2004: 803) and Clapp-Smith, Vogelgesang and Avey (2009: 232) posit that authentic leadership contributes to employee trust and as a result increases performance. Grandey, Fiske, Mattila, Jansen and Sideman (2005: 42) reported a positive relationship between authentic leadership and business performance. The following hypothesis is subjected to testing in this study:
$H^{2}$ : There is a positive relationship between the family business owner displaying Authentic leadership and the Perceived business performance of the family business.

Anecdotal evidence suggests that a positive relationship exists between participative leadership and business performance (Duggan, 2014; Goode, 2014; Henson, 2012). For example, Duggan (2014) contends that participative leaders recognise that building and establishing an effective team often leads to sustainable growth and profitability, both of which are outcomes of business performance. Several empirical studies (Abiodun \& Siddiq, 2013: 4; Ogbonna \& Harris, 2000: 767) have also found positive relationships between participative leadership and business performance. According to Kim (2002: 236), management participation, employee involvement and shared decision-making in businesses lead to improved performance and increased employee satisfaction within businesses. Sorenson (2000: 194) has found that participative leadership significantly contributes to the financial performance of small family businesses. Given this discussion, the following hypothesis is subjected to empirical testing in this study:

\section{$H^{3}$ : There is a positive relationship between the family business owner displaying Participative leadership and the Perceived business performance of the family business.}

Several scholars have examined the influence of servant leadership on business performance (e.g. Ebener \& O'Connell, 2010: 316; Indartono, Chiou \& Chen, 2010: 42; Melchar \& Bosco, 2010: 76; Jaramillo, Grisaffe, Chonko \& Roberts, 2009: 257; Joseph \& Winston, 2005: 11). According to Mishler (2012: 27), high performance and business success require that leaders of businesses implement a servant leadership style. Melchar and Bosco (2010: 77) found that leaders displaying servanthood (a characteristic of servant leadership) assist in building a business climate that generates employee empowerment and ultimately improved business performance (Liden, Wayne, Zhao \& Henderson, 2008: 164). Similarly, Joseph and Winston (2005: 16) assert that servant leadership has the potential to improve a business's productivity and business performance. According to Melchar and Bosco (2010: 84), servant leadership provides a successful alternative to the traditional autocratic, transformational and transactional leadership styles, and when compared to transactional leaders, for example, servant leaders are perceived to generate higher levels of business performance (Bass \& Avolio, 2000 in Choudhary et al., 2013: 434). Against this background the following hypothesis has been formulated:

$H^{4}$ : There is a positive relationship between the family business owner displaying Servant leadership and the Perceived business performance of the family business.

\section{Research design and methodology}

The research design and methodology adopted for this study was subjected to the research ethics approval procedures at 
the Nelson Mandela Metropolitan University and it was deemed that no potential harm to the respondents exists.

\section{Sampling procedure and response rate}

Convenience sampling was used to identify 250 small and medium-sized family businesses operating within the borders of the Eastern Cape Province. These small businesses were approached and the family business owner and an employee of that business were requested to complete a questionnaire. This approach resulted in 500 potential respondents (250 family business owners and 250 family business employees). For the purpose of this study a family business refers to a business where at least two family members actively work in the business, where a single family owns more than 50 percent shares in the business and the business employs more than five but fewer than 200 full-time employees. A family business owner refers to the owner of such a business and an employee refers to a person working in such a business.

\section{Measuring instrument and data collection}

The measuring instrument consisted of a cover letter and three sections. Two questionnaires were administered, one was completed by the family business owner and the other by the family business employee. These questionnaires had the same questions, but where necessary, the statements relating to the leadership styles were worded differently. This difference in wording was necessary so as to measure the family business owners' perceptions of their own leadership style (business owner questionnaires) and the employees' perceptions of the leadership style displayed by the owner (employee questionnaire).

Section A requested demographic information relating to the respondents, the family business and a question that required the respondents to verify whether they met the requirements for participating in the research. Section $B$ of the questionnaire consisted of 44 statements (items) describing the leadership style of the owner of the family business.
Respondents were requested to indicate the extent to which they agreed or disagreed with each statement. Family business owners were requested to indicate whether the statements described their leadership style, and family business employees were asked whether the statements described the leadership style of their family business employer. Section C consisted of 6 statements (items) measuring the financial performance of the family business. A 5-point Likert type scale interpreted as: Strongly agree (5), Agree (4), Neutral (3), Disagree (2), and Strongly disagree (1) was used to measure the extent of agreement or disagreement with the statements in Section B and C.

The family business owners and an employee working in the family business identified through the sampling technique were approached by fieldworkers and asked to participate in the study. Willing respondents were given the questionnaire in person and these were collected by the fieldworker upon completion. The completed questionnaires were examined and usable questionnaires were numbered; the data was then captured onto an Excel spread sheet and prepared for statistical analysis. Of the 217 family businesses that returned questionnaires, 133 from family business owners and 133 from family business employees were usable (266 questionnaires in total). The effective response rate was 53.20 percent.

\section{Scale development and operationalization}

Several studies (see Table 1) were consulted to identify items measuring the leadership styles (independent variables) investigated in this study. Although these styles are seen as consisting of several dimensions, they were considered higher-order single constructs in this study. Such consideration is not uncommon in the literature (Wang et al., 2014; Cooper, Scandura \& Schriesheim, 2005). The dimensions considered, the number of items and the sources of these items for each of the leadership styles, as well as Perceived business performance can be found in Table 1.

Table 1: Scales measuring leadership styles and Perceived business performance

\begin{tabular}{|c|c|c|c|}
\hline $\begin{array}{l}\text { Leadership } \\
\text { style }\end{array}$ & Dimensions & Items & Source \\
\hline Ethical & $\begin{array}{l}\text { Integrity } \\
\text { Ethical commitment }\end{array}$ & 11 & $\begin{array}{l}\text { Yukl et al. (2013); Kalshoven et al. (2011); Liden et al. } \\
\text { (2008); Khuntia and Suar (2004); Page and Wong (2000). }\end{array}$ \\
\hline Authentic & $\begin{array}{l}\text { Relational transparency } \\
\text { Internalised moral perspective }\end{array}$ & 8 & $\begin{array}{l}\text { Yukl et al. (2013); Northouse (2012); Walumbwa et al. } \\
\text { (2008); Page and Wong (2000). }\end{array}$ \\
\hline Participative & $\begin{array}{l}\text { Management participation } \\
\text { Autonomy }\end{array}$ & 10 & $\begin{array}{l}\text { Kalshoven et al. (2011); Liden et al. (2008); Khuntia and } \\
\text { Suar (2004); Page and Wong (2000). }\end{array}$ \\
\hline Servant & $\begin{array}{l}\text { Humility } \\
\text { Servanthood } \\
\text { Caring for others }\end{array}$ & 15 & $\begin{array}{l}\text { Yukl et al. (2013); Kalshoven et al. (2011); Liden et al. } \\
\text { (2008); Walumbwa et al. (2008); Barbuto and Wheeler } \\
\text { (2006); Khuntia and Suar (2004); Page and Wong (2000). }\end{array}$ \\
\hline $\begin{array}{l}\text { Perceived } \\
\text { business } \\
\text { performance }\end{array}$ & $\begin{array}{l}\text { Business is profitable, successful and financially } \\
\text { secure } \\
\text { Growth in profits, turnover, and number of } \\
\text { employees }\end{array}$ & 6 & $\begin{array}{l}\text { Matchaba-Hove (2013); Eybers (2010); Farrington } \\
\text { (2009). }\end{array}$ \\
\hline
\end{tabular}

Based on the scales developed the leaderships styles were operationalised as follows, Ethical leadership: The family business owner acting with integrity, and being committed to behaving ethically. Authentic leadership: The family 
business owner displaying relational transparency and demonstrating an internalised moral perspective. Participative leadership: The family business owner displaying management participation and autonomy within the family business. Servant leadership: The family business owner displaying humility, servanthood, and caring for others. Perceived business performance will be measured in terms of both the perceived growth and profitability of the family business and will be operationalised as the family business being profitable, successful and financially secure, as well as experiencing growth in profits, turnover, and number of employees over the last two years.

\section{Data analysis}

The data analysis involved assessing the validity and reliability of the measuring instrument. Thereafter, descriptive statistics such as the mean, standard deviation and frequency distributions were calculated to summarise the sample data. T-tests were conducted to determine whether differences in mean scores reported for the various leadership styles under investigation were statistically significant, and Cohen's d statistic was calculated to determine practical significance. Cohen's d values of greater than 0.2 but less than 0.5 reflect differences of small practical significance; values of greater than 0.5 but less than 0.8 reflect differences of moderate practical significance, whereas values of greater than 0.8 reflect difference of large practical significance (Gravetter \& Wallnau, 2011: 233). Pearson's product moment correlations were calculated to establish the correlations between the factors under investigation. Multiple regression analysis (MRA) was done to test the hypothesised relationships between the independent and dependent variables. The software programme Statistica 13 was used to perform the various analyses.

\section{Empirical results}

\section{Sample demographics}

The majority (75.94\%), of family business owner respondents were male and between the ages of 40 and 49 (36.84\%) or over 50 years of age $(38.35 \%)$. The majority were also White $(57.89 \%)$, followed by Asian/Coloured $(28.81 \%)$, and Black $(16.54 \%)$. The majority $(59.40 \%)$ indicated that they were in possession of a tertiary education and that they had been the owner of their family business for less than 10 years $(59.40 \%)$. For the family business employee sample group, a fairly equal number of male $(46.62 \%)$ and female $(52.63 \%)$ respondents participated. The majority were 29 years or younger $(39.85 \%)$ or between the ages of 30 and $39(27.82 \%)$ years. Most $(44.36 \%)$ employees were White, followed by Asian/Coloured (24\%) and Black (30.83\%), respondents. The majority $(54.89 \%)$ indicated that they did not possess a tertiary education. The great majority of the family business employees had been employed in the family business for less than 10 years $(84.47 \%)$. The majority of the family businesses $(69.92 \%)$ that participated in the study were started by the first generation (i.e. the current generation), with only 18.80 per cent being in their second generation. Most of the family businesses employed fewer than 10 employees $(63.16 \%)$ and between 11 and 25 employees (27.07\%). Only 2.26 percent of the family businesses employed more than 51 employees. Most of the family businesses operated in service (37.59\%) or retailer and/or wholesaler $(32.33 \%)$ industries.

\section{Results of the validity and reliability assessments}

An exploratory factor analysis (EFA) was undertaken to assess the validity of the scales measuring the independent and dependent variables. The data collected from both the family business owner and the family business employee respondents was included in this analysis. Factor loadings of greater than 0.5 were considered significant (Hair, Black, Babin \& Anderson, 2014: 114). Items that cross-loaded were eliminated, and only factors with two or more items loading onto them were considered for further statistical analysis. Five factors were extracted from the EFA explaining 50.60 per cent of the variance in the data. Only four of the factors were considered for further analysis as the fourth factor extracted had only one item that loaded onto it.

The four usable factors extracted could be identified as the theoretical dimensions of Ethical leadership, Participative leadership, Perceived business performance and Servant leadership. The items measuring Ethical and Authentic leadership did not load as expected, as several items measuring these two leadership styles loaded together onto one factor. Brown and Treviño (2006: 599) are of the opinion that authentic leadership is built on the foundations of ethical leadership, so it is not surprising that the items measuring these two leadership styles loaded together onto one factor. Based on the nature of the items loading onto this factor the name Ethical leadership was retained. Of the ten items originally developed to measure Participative leadership, only nine loaded together onto this factor. One of the items measuring Servant leadership also loaded onto this factor. Only five of the fifteen items intended to measure Servant leadership loaded together as expected. Items that did not load were eliminated. All six items intended to measure the dependent variable Perceived business performance loaded together as expected.

Cronbach's alpha coefficients were calculated to assess the reliability of the measuring instrument. For all factors coefficients of greater than 0.7 (Nunnally, 1978: 226) were returned. Sufficient evidence of validity and reliability for the scales measuring the independent and dependent variables is thus provided. The validity and reliability results are summarised in Table 2.

\section{Revised operational definitions and hypotheses}

Based on the results of the validity and reliability analyses, the operational definitions were rephrased (see Table 2) and the hypotheses reformulated. As a result of the EFA, Authentic leadership was no longer subjected to empirical testing in this study. 
Table 2: Reformulated operational definitions and validity and reliability results

\begin{tabular}{|c|c|c|c|}
\hline Operationalisation of factors & Items & Factor loadings & CA \\
\hline $\begin{array}{l}\text { Perceived business refers to the family business being profitable, financially successful and secure, } \\
\text { as well as experiencing growth in profit, turnover and employees over the past two years. }\end{array}$ & 6 & $\begin{array}{l}\text { Max: } 0.880 \\
\text { Min: } 0.653\end{array}$ & .889 \\
\hline $\begin{array}{l}\text { Ethical leadership: A style of leadership in which the family business owner displays a strong } \\
\text { concern for and is guided by ethical and moral values, is fair, honest and trustworthy, keeps his/her } \\
\text { promises, and practices what he/she preaches. }\end{array}$ & 15 & $\begin{array}{l}\text { Max: } 0.705 \\
\text { Min: } 0.512\end{array}$ & .914 \\
\hline $\begin{array}{l}\text { Participative leadership: A style of leadership characterised by involving subordinates in planning, } \\
\text { goal-setting and decision-making, encouraging independent decision-making, and a sense of } \\
\text { ownership, sharing authority and responsibility, and learning from subordinates. }\end{array}$ & 10 & $\begin{array}{l}\text { Max: } 0.766 \\
\text { Min: } 0.542\end{array}$ & .873 \\
\hline $\begin{array}{l}\text { Servant Leadership: A style of leadership in which the family business owner is approachable and } \\
\text { acknowledges dependency upon subordinates, pays attention to the personal needs of subordinates, } \\
\text { genuinely cares for their welfare, and goes out of his/her way to help them. }\end{array}$ & 5 & $\begin{array}{l}\text { Max: } 0.806 \\
\text { Min: } 0.563\end{array}$ & .860 \\
\hline
\end{tabular}

The renumbered hypotheses are as follows:

$H^{1}$ : There is a positive relationship between the family business owner displaying Ethical leadership and the Perceived business performance of the family business.

$H^{2}$ : There is a positive relationship between the family business owner displaying Participative leadership and the Perceived business performance of the family business.

$H^{3}$ : There is a positive relationship between the family business owner displaying Servant leadership and the Perceived business performance of the family business.

\section{Descriptive statistics and correlations}

The results of the descriptive statistics are summarised in Table 3 for the family business owners and in Table 4 for the family business employees. For discussion purposes, response categories on the 5-point Likert scale for both the dependent and independent variables were categorised as follows: responses from $1 \leq \mathrm{x} \leq 2.333$ were categorised as disagree; $2.333 \leq \mathrm{x} \leq 3.667$ categorised as neutral; and 3.667 $\leq \mathrm{x} \leq 5.000$ were categorised as agree.

Table 3: Descriptive statistics for family business owners $(\mathrm{N}=133)$

\begin{tabular}{l|c|c|c|c|c}
\hline Factors & Mean & Std. Dev & Disagree \% & Neutral \% & Agree \% \\
\hline Ethical leadership & 4.484 & 0.380 & 0.000 & 1.504 & 98.496 \\
\hline Participative leadership & 3.692 & 0.611 & 3.008 & 37.594 & 59.398 \\
\hline Servant leadership & 4.213 & 0.530 & 0.000 & 12.030 & 87.970 \\
\hline Perceived business performance & 3.947 & 0.793 & 3.759 & 21.053 & 75.188 \\
\hline
\end{tabular}

Table 4: Descriptive statistics for family business employees $(\mathrm{N}=133)$

\begin{tabular}{l|c|c|c|c|c}
\hline Factors & Mean & Std. Dev & Disagree \% & Neutral \% & Agree \% \\
\hline Ethical leadership & 4.213 & 0.550 & 0.752 & 11.278 & 87.970 \\
\hline Participative leadership & 3.650 & 0.611 & 4.511 & 36.842 & 68.647 \\
\hline Servant leadership & 4.021 & 0.693 & 2.256 & 22.556 & 75.118 \\
\hline
\end{tabular}

The dependent variable Perceived business performance returned a mean score of 3.947 for the family business owner sample group, with the majority of respondents agreeing that their businesses were profitable, financially successful and secure, and had experienced growth in profit, turnover and employee numbers over the past two years. The independent variables investigated (leadership styles) returned mean scores of between 3.692 and 4.484 for the family business owner sample group, and between 3.650 and 4.213 for the family business employees sample group. For both sample groups Ethical leadership returned the highest mean score, followed by Servant and then Participative leadership. The majority of respondents agreed that the leadership styles investigated were evident in the family businesses in which they were involved. In addition, significant and positive correlations are reported between all variables for both sample groups.

\section{T-tests}

T-tests were undertaken to determine whether the differences in mean scores returned by the family business owner and the family business employee sample groups for the leadership styles under investigation, were significantly different from each other. The results (see Table 5) show a significant difference $(\mathrm{p}<0.001)$ between the mean scores returned by the family business owners and the family business employees with regard to the level of Ethical leadership displayed by the family business owner. Family business owners returned a higher mean score $(\bar{X}=4.484)$ than family business employees $(\bar{X}=4.213)$ did. In other words, family business owners perceived themselves as displaying Ethical leadership more than family business employees perceived that family business owners did. A Cohen's d value of 0.557 indicates this difference to be of moderate practical significance. 
Table 5: Results of t-tests

\begin{tabular}{l|c|c|c|c|c}
\hline Factors & Mean FBO & Mean FBE & t-value & Sig.(p) & Cohen's d \\
\hline Ethical leadership & 4.484 & 4.213 & $\mathbf{4 . 6 8 4}$ & $\mathbf{0 . 0 0 0} * *$ & $0.577 \#$ \\
\hline Participative leadership & 3.692 & 3.500 & 0.538 & 0.591 & 0.066 \\
\hline Servant leadership & 4.213 & 4.021 & $\mathbf{2 . 5 4 1}$ & $\mathbf{0 . 0 1 2} *$ & $0.313 \#$ \\
\hline
\end{tabular}

(FBO = Family business owners; FBE = Family business employees); (*p < 0.05; **p < 0.001); (\# Small practical significance; \#\# Moderate practical significance).

The t-test also showed a statistically significant difference (p $<0.05$ ) between the mean scores returned by the family business owners and the family business employees with regard to Servant leadership. The family business owners returned higher mean scores $(\bar{x}=4.213)$ than the family business employees $(\bar{x}=4.021)$ did. Therefore, family business owners perceived themselves as being servant leaders more than their employees perceived that they were. A Cohen's $d$ value of 0.313 , however, indicates this difference to be of small practical significance. The t-test revealed no significant difference between the mean scores returned by the family business owners and the family business employees with regard to Participative leadership.

\section{Multiple regression analysis}

Multiple regression analysis (MRA) was undertaken to assess whether the levels of Ethical, Participative and Servant leadership have a significant influence on the dependent variable, Perceived business performance. The t-tests undertaken (see results Table 5) showed that significant differences in mean scores for the levels of Ethical and Servant leadership displayed by the family business owner were reported between the family business owner and family business employee sample groups. In both cases the family business owners reported higher mean scores. In addition, although the difference was not significant, family business owners returned a higher mean score for Participative leadership than family employees did. The aforementioned differences imply that a degree of socially desirable bias could exist in the data. Self-report questionnaires are vulnerable to social desirability bias, and the results are often inflated owing to respondents' tendencies to answer in a more socially acceptable way. This is a problem, as social desirability bias compromises the validity and quality of data (Kim \& Kim, 2013: 1). Given these biases, it was the view of the researchers that the perceptions held by the family business employees of the levels of Ethical, Participative, and Servant leadership displayed by the family business owners would be a more accurate and objective perception than the one held by the family business owners of themselves. Therefore, in order to assess the hypothesised relationships between the independent and the dependent variable in this study, the levels of Ethnical, Participative and Servant leadership as perceived by the family business employees only were considered for analysis. With regard to the dependent variable, Perceived business performance, it was the view of the researchers that the family business owner would be in a better position to provide an opinion of the performance of his or her business than the family business employee would. For this reason, the dependent variable Perceived business performance was based on the perception of the family business owner. The Perceived business performance of the family business in which the employee worked, as reported by the family business owner of that same business, was therefore used as the dependent variable.

In order to establish whether multi-collinearity is a problem in the present study, the variance inflation factors (VIF) were calculated. VIF of less than 4 (O'Brien, 2007: 674) were reported for all independent variables (see Table 6) and multicollinearity was not considered a problem when undertaking the multiple regression analysis. In the multiple regression analysis the demographic variables gender, ethnicity, possession of a tertiary qualification and age were controlled for to account for possible confounding influences. The results of the MRA show that the independent variables explain only 7.77 percent of the variance in Perceived business performance. In addition, none of the demographic variables controlled for report a significant influence on Perceived business performance. From Table 6 it can be seen that no relationships were reported between Ethical, Participative and Servant leadership, and the dependent variable Perceived business performance. In other words, whether or not these leadership styles were perceived by employees as displayed by the family business owner for whom they worked, or not, had no influence on the performance of the family business. Against this background, no support was found for the hypothesised relationships between the Ethical leadership $\left(\mathrm{H}^{1}\right)$, Participative leadership $\left(\mathrm{H}^{2}\right)$ and Servant leadership $\left(\mathrm{H}^{3}\right)$, and the dependent variable Perceived business performance. 
Table 6: Influence of the independent variables on Perceived business performance

\begin{tabular}{|c|c|c|c|c|}
\hline \multicolumn{3}{|c|}{ Dependent variable: Perceived business performance } & \multicolumn{2}{|c|}{ R-Square $=\mathbf{0 . 0 7 7}$} \\
\hline Independent variables & VIF & Beta & t-value & Sig.(p) \\
\hline Intercept & & 2.5819 & 3.973 & 0.0000 \\
\hline Gender & - & -0.0602 & -0.419 & 0.6760 \\
\hline Ethnicity & - & -0.0866 & -1.008 & 0.3152 \\
\hline Tertiary qualification & - & 0.2135 & 1.510 & 0.1336 \\
\hline Age & - & -0.0150 & -0.244 & 0.8076 \\
\hline Ethical leadership & 0.443 & 0.2150 & 1.206 & 0.2300 \\
\hline Participative leadership & 0.991 & 0.0091 & 0.069 & 0.9447 \\
\hline Servant leadership & 1.269 & 0.1059 & 0.698 & 0.4864 \\
\hline
\end{tabular}

$$
\text { *p }<0.05 ; * * \mathrm{p}<0
$$

\section{Discussion and conclusions}

The findings of this study showed that for both family business owners and family business employees, Ethical leadership returned the highest mean score, followed by Servant and then Participative leadership. The majority of family business owners agreed that they displayed these leadership styles as did the majority of family business employees agree that their employers displayed these style. The percentages agreeing that a Participative leadership was displayed by the family business owner were much lower than the other styles for both sample groups.

The high levels of Ethical, Participative and Servant leadership perceived to be displayed by the family business owner participating in this study somewhat contradict the literature which suggests that family business owners are often autocratic and directive in their style of leadership (Marshall, 2001: 11; Sorenson, 2000: 185). The findings of this study could be attributed to the nature of the sample. The majority $(70 \%)$ of family businesses that participated were in their first generation. According to Lucas (2012), first generation leaders tend to take the role of the leader and decision maker upon themselves. The aforementioned also provides a possible explanation as to why Participative leadership scored the lowest mean score amongst both family business owners and employees respondents. Furthermore, most of the family business owners interviewed were in possession of a tertiary qualification, while most of the employees were not. It is possible to suggest that leaders with a tertiary qualification are more educated and are therefore more aware of the benefits and results that arise from being more ethical, caring, serving and participative.

The findings of this study revealed that family business owners returned higher mean score for both Ethical leadership and Servant leadership than family business employees did. In other words, family business owners perceive themselves as displaying Ethical and Servant leadership more so than family business employees perceived that family business owners do. These differences in perceptions are not surprising given that socially desirable bias occurs when individuals describe or rate themselves in a manner that is untruthful, or in a way that they feel may be viewed favourably by others (Zikmund \& Babin, 2013: 289). According to Kreuter, Presser and Tourangeau (2008: 848), socially desirable bias occurs more often in studies that include a high number of sensitive questions. A possible explanation for the findings in this study could be the sensitive nature of several questions in the measuring instrument.

No relationships were reported between the independent variables (Ethical, Participative and Servant leadership) and the dependent variable Perceived business performance. These findings contradict those of several others (Bello, 2012: 231; Strider, 2011) who report positive relationships between ethical leadership and business performance. The findings of Duggan (2014), Cherry (2014), Abiodun and Siddiq (2013: 4) as well as Ogbonna and Harris (2000: 767) also contradict the findings of this study. These authors found positive relationships between both participative and servant leadership, and business performance.

A possible explanation for the findings in this study is that the leadership style adopted in the participating family businesses plays an important role in enhancing the interest and level of commitment amongst employees (Ojokuku, Odetayo \& Sajuyigbe, 2012: 202), rather than influencing business performance directly. The results of the MRA show that the leadership styles investigated only explain 7.77 percent of the variance in Perceived business performance. Therefore, it appears that other factors have a far greater influence on business performance than the styles investigated in this study. For example, Chi and Gursoy (2009: 245), as well as Harter, Schmidt and Hayes (2002: 268), found that employee and customer satisfaction influence business performance. Therefore, implementing a leadership style that focuses on improving customers and employee satisfaction is possibly more likely to positively influence the overall performance of the family business. Another possible explanation is that the researchers have measured the ethical behaviour of the family business owner based on the perceptions of his or her employees. The perception of an employee, however, may not be an accurate or true reflection of the actual ethical behaviour of the owner. The owner could be hiding his or her unethical practices, and hence the influence on performance is not evident in the results of this study.

Although the MRA analysis revealed no statistically significant relationships between the leadership styles investigated and Perceived business performance, ample empirical and anecdotal evidence exists in the literature to support this relationship. Therefore, if family business 
owners implement more value-laden leadership styles in their family businesses, theory suggests that improved business performance should result. In this study, the majority of respondents agreed that the leadership styles investigated were evident in the family businesses in which they were involved. For both sample groups Ethical leadership returned the highest mean score, followed by Servant and Participative leadership. The importance of these valueladen leadership styles to family businesses is thus highlighted contradicting the literature (Marshall, 2001: 11; Sorenson, 2000: 185) purporting that family business owners are often autocratic and directive in their style of leadership.

This study has made a contribution in that it has responded to several calls (Xi et al., 2015: 129; Sharma, 2004: 11) in the literature for more research on leadership in the field of family business. More specifically an increased understanding of the use of Ethical leadership, Servant and Participative leadership among family business owners has occurred. In addition, an increased understanding of the effectiveness of these styles in the context of family businesses has resulted.

\section{Limitations and future research}

The use of non-random samples remains an on-going problem in family business research where databases are not freely accessible. The results of the EFA showed that several items measuring the leadership styles investigated did not load together as expected. As a result, Authentic leadership and Ethical leadership were investigated as a single construct. Scales measuring Authentic leadership should be redeveloped to ensure that the influence of this leadership style can be assessed as a separate construct. This study focused on Perceived business performance as the dependent variable. Future research could consider adding mediating variables such as job satisfaction and organisational commitment. The present study focused on certain valueladen leadership styles only. Leadership styles such as transformational and transactional leadership, which could possibly influence perceived business performance, were not considered.

\section{Acknowledgement}

The authors would like to acknowledge the contributions of Ms A. de Wit in the completion of this article.

\section{References}

Abiodun, O.A. \& Siddiq, M.S.B. 2013. 'Organizational culture, leadership and performance in Nigeria: Moderating effect of ethical decision making', International Academic Research, 2(7): 1-9.

Acs, Z., Glaeser, R., Litan, L. \& Fleming, S. 2008. Entrepreneurship and urban success. Kansas City: Ewing Marion.

Aldrich, H.E. \& Cliff, J.E. 2003. IN Sharma, P. 2004. 'An overview of the field of family business studies: Current status and directions for the future', Family Business Review, 17(1): 1-36.
Aronoff, C.E. \& Baskin, O.W. 2011. Effective leadership in the family business. A family business publication. USA: Palgrave Macmillan.

Avolio, B.J., Gardner, W.L., Walumbwa, F.O., Luthans, F. \& May, D.R. 2004. 'Unlocking the mask: A look at the process by which authentic leaders impact follower attitudes and behaviours', The Leadership Quarterly, 15(2004): 801-823.

Avolio, B.J., Walumbwa, F.O. \& Weber, T.J. 2009. 'Leadership: Current Theories, Research and Future Directions', Annual Review of Psychology, 60(1): 421-449.

Barbuto, J.E. \& Wheeler, D.W. 2006. 'Scale development and construction clarification of servant leadership', Group \& Organizational Management, 31(3): 300-326.

Bass, B. \& Avolio, B.J. 2000. IN Choudhary, A.I., Akhtar, S.A. \& Zaheer, A. 2013. 'Impact of transformational and servant leadership on organisational performance: A comparative analysis', Journal of Business Ethics, 116(2): 433-440.

Bello, S.M. 2012. 'Impact of ethical leadership on employee job performance', International Journal of Business and Social Sciences, 3(11): 228-236.

Benavides-Velasco, C.A., Quintana-Garcia, C. \& Guzman-Parra, V.F. 2013. 'Trends in family business research', Small Business Economy, 40(1): 41-57.

Berghoefer, D. \& Schwartz, G. 2014. Ethical leadership: Right relationships and the emotional bottom line. The gold standard for success. [online] www.ethicalleadership.com/BusinessArticle.htm

Berrone, P., Cruz, C. \& Gomez-Mejia, L.R. 2012. 'Socioemotional wealth in family firms: Theoretical dimensions, assessment approaches, and agenda for future research', Family Business Review, 25(3): 258-279.

Brown, M.E. \& Trevino, L.K. 2006. 'Ethical leadership: A review and future directions', The Leadership Quarterly, 17(2006): 595616.

Brown, M.E., Trevino, L.M. \& Harrison, D. 2005. 'Ethical leadership: A social learning perspective for construct development and testing', Organizational Behaviour and Human Decision Process, 97(2): 117-134.

Ceja, L., Agulles, R. \& Tàpies, J. 2010. Importance of values in family-owned firms. Working paper, WP-875, University of Navarra: IESE Business School, Madrid, Spain.

Cherry, K. 2014. What is democratic leadership? [online] http://psychology.about.com/od/leadership/f/democraticleadership.htm

Chi, C.G. \& Gursoy, D. 2009. 'Employee satisfaction, customer satisfaction, and financial performance: An empirical examination', International Journal of Hospitality Management, 28(2): 245-253.

Choudhary, A.I., Akhtar, S.A. \& Zaheer, A. 2013. 'Impact of transformational and servant leadership on organisational performance: A comparative analysis', Journal of Business Ethics, 116(2): 433-440.

Clapp-Smith, R., Vogelgesang, G. \& Avey, J. 2009. 'Authentic leadership and positive psychological capital: The mediating role of 
trust at the group level analysis', Organizational Studies, 15(2) 227240 .

Cooper, C.D., Scandura, T.A. \& Schriesheim, C.A. 2005. 'Looking forward but learning from our past: Potential challenges to developing authentic leadership theory and authentic leaders', The Leadership Quarterly, 16(2005): 475-493.

Davis, J.A. 2014. Managing the family business: Leadership roles. [online] http://hbswk.hbs.edu/item/7404.htm

Dyer, W.G. 1986. IN Sorenson, R.L. 2000. 'The contribution of leadership style and practices to family and business success', Family Business Review, 13(3): 183-200.

Duggan, T. 2014. About participative leadership style \& front office performance. [online] http://smallbusiness.chron.com/participativeleadership-style-front-office-performance-10256.html

Ebener, D.R. \& O'Connell, D.J. 2010. 'How might servant leadership work?', Nonprofit Management and Leadership, 20(3): 315-335.

Eybers, C. 2010. Copreneurships in South African small and medium-sized family businesses. Unpublished masters dissertation, Nelson Mandela Metropolitan University, Port Elizabeth, South Africa.

Farrington, S.M. 2009. Sibling partnerships in South African small and medium-sized family businesses. Unpublished doctoral thesis, Nelson Mandela Metropolitan University, Port Elizabeth, South Africa.

Gardner, W.L. \& Schermerhorn, J.R. 2004. 'Unleashing individual potential: Performance gains through positive organizational behavior and authentic leadership', Organizational Dynamics, 33(3): 270-281.

Gardner, W.L., Avolio, B.J., Luthans, F., May, D.R. \& Walumbwa, F. 2005. 'Can You See the Real Me? A Self-Based Model of Authentic Leader Follower Development', Leadership Quarterly, 16: $343-372$.

Gini, A. 1997. 'Moral leadership: An overview', Journal of Business Ethics, 16(3): 323-330.

Global data points. 2014. The FFI Practitioner. [online] www.ffi.org/?page=GlobalDataPoints

Gomez-Mejia, L.R., Cruz, C., Berrone, P. \& De Castro, J. 2011. 'The bind that ties: Socio-emtional wealth preservation in family firms', The Academy of Management Annals, 5(1): 653-707.

Goode, E. 2014. How participative leadership can improve your organization. [online] http://ericgoode.hubpages.com/hub/ Participative-Leadership

Grandey, A., Fiske, G., Mattila, A., Jansen, K. \& Sideman, L. 2005. 'Is service with a smile enough? Authenticity of positive displays during service encounters', Organizational Behavior and Human Decision Processes, 96(2005): 38-55.

Gravetter, F.J. \& Wallnau, L.B. 2011. Essentials of statistics for the behavioral sciences. 7th Edition. California: Cengage Learning.

Hackett, R.D. \& Wang, G. 2012. 'Virtues and leadership: An integrating conceptual framework found in Aristotelian and
Confucian perspectives on virtues', Management Decision, 50(5): 868:899.

Hair, J.F., Black, W.C., Babin, B.J. \& Anderson, R.E. 2014. Multivariate data analysis. 7th Edition. New Jersey: Pearson.

Harter, J.K., Schmidt, F.L. \& Hayes, T.L. 2002. 'Business-unit-level relationship between employee satisfaction, employee engagement, and business outcomes: A meta-analysis', Journal of Applied Psychology, 87(2): 268-279.

Henson, R. 2012. How participative leadership boosts morale, productivity. [online] http://blog.manageelitetraining.com/ leadership-boost-morale/

Ibrahim, A.B., McGuire, J. \& Soufani, K. 2009. 'An empirical investigation of factors contributing to longevity of small family firms', Global Economy and Finance Journal, 2(2): 1-21.

Indartono, S., Chiou, H. \& Chen, C.V. 2010. 'The joint moderating impact of personal job fit and servant leadership on the relationship between the task characteristics of job design and performance', Interdisciplinary Journal of Contemporary Research in Business, 2(8): 42-61.

Jaramillo, F., Grisaffe, D.B., Chonko, L.B. \& Roberts, J.A. 2009. 'Examining the impact of servant leadership on sales force performance', Journal of Personal Selling \& Sales Management, 29(3): 257-275.

Jing, F.F. \& Avery, G.C. 2008. 'Missing links in understanding the relationship between leadership and organizational performance', International Business \& Economic Research Journal, 7(5): 67-78.

Joseph, E. \& Winston, B. 2005. 'A Correlation of servant leadership, leader trust, and organizational trust', Leadership \& Organizational Development Journal, 26(1): 6-22.

Kaiser, R.B., Hogan, R. \& Craig, S.B. 2008. 'Leadership and the fate of organizations', American Psychologist Association, 63(2): 96110 .

Kalshoven, K., Den Hartog, D.N. \& De Hoogh, A.H.B. 2011. 'Ethical leadership at work questionnaire (ELW): Development and validation of a multidimensional measure', The Leadership Quarterly, 22(1): 51-69.

Kar, S. 2009. 'Ethical leadership: Best practice for success', Journal of Business and Management, 1(14): 112-116.

Khuntia, R. \& Suar, D. 2004. 'A scale to assess ethical leadership of Indian private and public sector managers', Journal of Business Ethics, 49(1): 13-26.

Kim, S. 2002. 'Participative management and job satisfaction: Lessons for management leadership', Public Administration Review, 62(2): 231-241.

Kim, S.H. \& Kim, S. 2013. 'National culture and social desirability bias in measuring public service motivation', Administration \& Society, $\mathbf{X X}(\mathrm{X})$ : 1-33.

Koontz, H. \& Weihrich, H. 2010. Essentials of management. 8th Edition. New Delhi: Tata Mcgraw-Hill. 
Kreuter, F., Presser, S. \& Tourangeau, R. 2008. 'Social desirability bias in CATI, IVR and web surveys: The effects of mode and question sensitivity', Public Opinion Quarterly, 72(5): 847-865.

Liden, R.C., Wayne, S.J., Zhao, H. \& Henderson, D. 2008. 'Servant leadership: Development of a multidimensional measure and multilevel assessment', The Leadership Quarterly, 19(2): 161-177.

Litz, R.A., Pearson, A.W. \& Litchfield, S. 2012. 'Charting the future of family business research: Perspectives from the field', Family Business Review, 25(1): 16-32.

Lucas, S.E. 2012. Protecting and growing your wealth. [online] www.ftpress.com/articles/article. aspx? $=2005111 \&$ seqNum $=7$

Lumpkin, G.T. \& Dess, G.G. 1996. 'Clarifying the entrepreneurial orientation construct and linking it to performance', Academy of Management Review, 21(1): 135-172.

Mahmood, R. \& Hanafi, N. 2013. 'Entrepreneurial orientation and business-performance of woman-owned small and medium enterprises in Malaysia: Competitive advantage as a mediator', International Journal of Business and Social Science. 4(1): 82-90.

Marshall, J.P. 2001. The impact of business owners' conflict management and leadership styles on succession planning in familyowned businesses. Unpublished masters dissertation, Graduate Faculty of Texas Tech University, Texas, USA.

Matchaba-Hove, T. 2013. The entrepreneurial orientation of small businesses in the Eastern Cape. Unpublished masters dissertation, Nelson Mandela Metropolitan University, Port Elizabeth, South Africa.

Melchar, D.E. \& Bosco, S.M. 2010. 'Achieving high organization performance through servant leadership', The Journal of Business Inquiry, 9(1): 74-88.

Michel, J.W., Lyons, B.D. \& Cho, J. 2011. 'Is the full-range model of leadership really a full-range model of effective leader behaviour?', Journal of Leadership and Organisational Studies, 18(4): 493-507.

Mishler, M.S. 2012. Eat more chicken and lead more people: Perceived measures of servant leadership at Chick-fil-A. Unpublished masters dissertation, Liberty University, Virginia, USA.

Myatt. M. 2009. The main reasons businesses fail. [online] https://myattleadershipmatters.wordpress.com/2009/07/16/themain-reason-businesses-fail/

Northouse, P.G. 2012. Leadership: Theory and practice. 6th Edition. Canada: Sage.

Nunnally, J.C. 1978. Psychometric Theory. 2nd Edition. New York: McGraw-Hill.

O'Brien, R.M. 2007. 'A caution regarding rules of thumb for variance inflation factors', Quality \& Quantity, 41(5): 673-690.

Ogbonna, E. \& Harris, L.C. 2000. 'Leadership style, organisational culture and performance: Empirical evidence from UK companies', International Journal of Human Resource Management, 11(4): 766788.
Ojokuku, R.M., Odetayo, T.A. \& Sajuyigbe, A.S. 2012. 'Impact of leadership style on organisational performance: A case study of Nigerian banks', American Journal of Business and Management, 1(4): 202-207.

Page, D. \& Wong, T.P. 2000. The human factor in shaping the course of history and development. (Chapter 5). Boston: University Press of America.

Pedraja-Rejas, L., Rodríguez-Ponce, E. \& Rodríguez-Ponce, Y.J. 2006. 'Leadership Styles and Effectiveness: A Study of Small Firms in Chile', Interscience, 31(7): 500-504.

Rushin, G. n.d. Causes of business failure and poor leadership. [online] http://garyrushin.com/my_blog/business-strategy-2/causesof-business-failure-and-poor-leadership/

Russell, R.F. \& Stone, G. 2002. 'A review of servant attributes: Developing a practical mode', Leadership \& Organization Development Journal, 23(3): 145-157.

Sendjaya, S., Sarros, J.C. \& Santora, J.C. 2008. 'Defining and measuring servant leadership behaviour in organisations', Journal of Management Studies, 45(2): 402-424.

Sharma, P. 2004. 'An overview of the field of family business studies: Current status and directions for the future', Family Business Review, 17(1): 1-36.

Somech, A. \& Wenderow, M. 2006. 'The impact of participative and directive leadership on teachers' performance: The intervening effects of job structuring, decision domain, and leader-member exchange', Education Administration Quarterly, 42(5): 746-772.

Soininen, J., Martikainen, M., Pumaonen, K. \& Kylaheiko, K. 2012. 'Entrepreneurial orientation: Growth and profitability of Finnish small and medium-sized enterprises', International Journal of Production Economics, 140(2): 614-621.

Song, M., Droge, C., Hanvanich, S. \& Calantone, R. 2005. 'Marketing and technology resource complementarily: An analysis of their interaction effect in two environmental contexts', Strategic Management Journal, 26(3): 259-276.

Sorenson, R.L. 2000. IN Sharma, P. 2004. 'An overview of the field of family business studies: Current status and directions for the future', Family Business Review, 17(1): 1-36.

Sorenson, R.L. 2000. 'The contribution of leadership style and practices to family and business success', Family Business Review, 13(3): 183-200.

Strider, S.H. 2011. Can ethical leadership be a predictor of success? [online] www.humanresourcesiq.com/business-strategies/articles/ can-ethical-leadership-be-a-predictor-of-success/

Tanzwani, M. 2010. An investigation of management succession planning in black-owned family businesses in selected areas in South Africa. Potchefstroom: North-West University.

Trevino, L.K., Brown, M. \& Hartman, L.P. 2003. 'A qualitative investigation of perceived executive ethical leadership: Perceptions from inside and outside the executive suite', Human Relations, 56(1): 5-37.

Tsai, W., MacMillan, I. \& Low, M. 1991. 'Effects of strategy and environment on corporate venture success in industrial markets', Journal of Business Venturing, 6(1):9-28. 
Van Dierendonck, D. 2011. 'Servant leadership: A review and synthesis', Journal of Management, 37(4): 1228-1261.

Walumbwa, F.O., Avolio, B.J., Gardner, W.L., Wernsing, T.S. \& Peterson, S.J. 2008. 'Authentic leadership: Development and validation of a theory-based measure', Journal of Management, 34(1): 89-126.

Wang, H., Sui, Y., Luthans, F., Wang, D. \& Wu, Y. 2014. 'Impact of authentic leadership on performance: Role of followers' positive psychological capital and relational process', Journal of Organizational Behavior, 35(1): 5-21.

Wiklund, J. \& Shepherd, D. 2003. 'Knowledge-based resources, entrepreneurial orientation, and the performance of small and medium-sized business', Strategic Management Journal, 24(13): $1307-1314$.

Wong, C.A. \& Laschinger, H.K.S. 2012. 'Authentic leadership, performance, and job satisfaction: The mediating role of empowerment', Journal of Advanced Nursing, 69(4): 947-959.

Xi, J.M., Kraus, S., Filser, M. \& Kellermanns, F.W. 2015. 'Mapping the field of family business research: Past trends and future directions', International Entrepreneurship and Management Journal, 11(1): 113-132.

Yukl, G., Mahsud, R., Hassan, S. \& Prussia, G.E. 2013. 'An improved measure of ethical leadership', Journal of Leadership \& Organizational Studies, 20(1): 38-48.

Zellweger, T. 2015. The 500 largest family firms in the world. [online] http://ffipractitioner.org/2015/05/20/the-500-largestfamily-firms-in-the-world

Zhu, W., May, D.R. \& Avolio, B.J. 2004. 'The impact of ethical leadership behaviour on employee outcomes: The roles of psychological empowerment and authenticity', Journal of Leadership \& Organizational Studies, 11(1): 16-26.

Zikmund, W.G. \& Babin, B.J. 2013. Essentials of marketing research. 5th Edition. Canada: Cengage. 